\title{
Alat Permainan Edukatif Maze Dua Sisi (MADASI) untuk Menstimulasi Keterampilan Sensori Motorik Anak
}

\section{Putu Perima Virianingsih 1* I Made Tegeh², Putu Rahayu Ujianti ${ }^{3}$}

\footnotetext{
1,3 Pendidikan Guru Pendidikan Anak Usia Dini, Universitas Pendidikan Ganesha, Singaraja, Indonesia
}

${ }^{2}$ Teknologi Pendidikan, Universitas Pendidikan Ganesha, Singaraja, Indonesia

\section{ART ICLE INF O}

Article history:

Received 15 January 2021 Revised 05 February 2021

Accepted 19 April 2021

Available online 25 April 2021

Kata Kunci:

Maze Dua Sisi, Sensori Motorik

Keywords:

Two Sided Maze, Motor Sensory

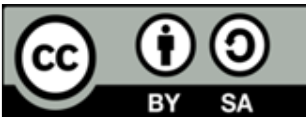

This is an open access article under the CC BY-SA license.

Copyright $($ C Universitas Pendidikan Ganesha. All rights reserved.

\begin{abstract}
A B S T R A K
Keterampilan sensori motorik anak sangat penting untuk di stimulasikan sejak dini, namun orangtua belum memahami perkembangan sensori motorik anak, sehingga kebingungan dalam memberikan media pembelajaran yang tepat untuk menstimulasi keterampilan sensori motorik anak. Penelitian ini bertujuan untuk mengembangkan alat permainan edukatif maze dua sisi (madasi) dan mengetahui hasil validitas alat permainan edukatif Maze Dua Sisi (Madasi) untuk menstimulasi keterampilan sensori motorik anak. Jenis penelitian ini adalah penelitian pengembangan dengan menggunakan model ADDIE yang terdiri atas Analis, Desain, Pengembangan, Implementasi, dan Evaluasi. Penelitian ini dilakukan hanya sampai pada tahap pengembangan. Subjek penelitian ini adalah anak kelompok A Taman Kanak-Kanak, sedangkan yang menjadi subjek uji coba dalam penelitian ini adalah ahli materi dan ahli media. Instrumen yang digunakan dalam penelitian ini adalah angket validasi ahli materi dan validasi ahli media. Teknik pengumpulan data yang digunakan dalam penelitian ini yaitu observasi dan angket. Analisis data dalam penelitian ini adalah analisis deskriptif kuantitatif. Hasil uji validitas yang dilakukan oleh ahli materi dan ahli media alat permainan edukatif Maze Dua Sisi (Madasi) mendapatkan nilai CVR dan CVI yaitu 1,00. Alat permainan edukatif Maze Dua Sisi (Madasi) dinyatakan valid dan layak digunakan untuk menstimulasi keterampilan sensori motorik anak. Implikasi penelitian ini diharapkan memberikan dampak pada keterampilan sensori motori anak menjadi lebih baik.
\end{abstract}

\section{A B S T R A C T}

Motor sensory skills of children are very important to be stimulated from an early age, but parents do not understand the child's motor sensory development, resulting in confusion in providing appropriate lesrning media to stimulate children's sensory motor skills. This study aims to develop a two sided maze educational tool and to identify the validity of the two sided maze (Madasi) educational game tool to stimulate motor sensory skills of children in Group A Kindergarten. The type of this dtudy was Development Research. The procedure of this study applied ADDIE model which consisted of Analysis, Design, Delevopment, Implementation, dan Evaluate. This study just ended at the Delevopment stage. The subjects of this study were children in group $A$ kindergarten. The test subjects in this study are material expert and media expert. The instruments used in this study were material expert validation questionnaires and media expert validation. The technique of data analysis used in this study was Qualitative Descriptive. The results of validation tests conducted by material experts and media experts, the two sided maze (Madasi) gets a CVR and CVI value of 1,00, the educational game toll is valid and suitable for use to stimulate motor sensory skills of children in Group A Kindergarten. The implications of this research are expected to have an impact on children's sensory motor skills for the better.

Copyright $($ C Universitas Pendidikan Ganesha. All rights reserved 


\section{Pendahuluan}

Pendidikan anak usia dini (PAUD) adalah jenjang pendidikan sebelum memasuki jenjang pendidikan dasar yang merupakan suatu upaya pembinaan yang ditujukan bagi anak sejak lahir sampai dengan usia enam tahun yang dilakukan melalui pemberian rangsangan pendidikan untuk membantu pertumbuhan dan perkembangan jasmani dan rohani agar anak memiliki kesiapan dalam memasuki pendidikan lebih lanjut, yang diselenggarakan pada jalur formal, nonformal, dan informal (Ananda, 2017; Nurdin \& Anhusadar, 2020). Standar pencapaian perkembangan usia anak meliputi aspek nilai agama, moral, fisik motorik, kognitif, bahasa, sosial emosional dan seni (Nurohmah \& Dewi, 2021; Wulandari \& Purwanta, 2021). Aspek-aspek perkembangan tersebut dapat berkembang dengan optimal apabila diberikan stimulasi yang tepat dan dilengkapi dengan alat-alat permainan pendukung lainnya (Lisa et al., 2020; Sasmito \& Trimulyono, 2019). Salah satu aspek perkembangan pada anak yang penting untuk distimulasikan yaitu, aspek sensori motorik, yang mana aspek ini dapat mempengaruhi aspek perkembangan anak selanjutnya seperti perkembangan bahasa, sosial emosi, kognitif (Juwantara, 2019; Rakhmayanti \& Subagio, 2019). Sensorimotorik merupakan tahap awal dalam perkembanga anak usia dini, dimana anak mengenali lingkungan sekitarnya melalui pengalaman indra dan pergerakannya. Dalam hal ini kegiatan anak lebih banyak di dominasi dengan terlibatnya sensori dan motorik anak, yang terdiri dari motorik halus dan motorik kasar. Sensori motorik sangat penting distimulasikan sejak dini, sebab sensorimotorik merupakan tahap perkembangan awal yang harus dilalui anak, agar nantinya anak tidak mengalami kesulitan dalam melanjutkan tugas perkembangannya, anak yang aktif dalam aktivitas sensorimotorik tentunya akan lebih mudah melewati perkembangan selanjutnya, sehingga anak menjadi lebih kuat, mandiri, cerdas dan percaya diri dimasa mendatang (Fhatri, 2020; Mulyani, 2019).

Perkembangan sensorimotorik ini sangat penting bagi anak, tahap sensorimotorik merupakan tahap awal yang ditandai dengan pemikiran anak berdasarkan pada tindakan inderawinya, proses adaptasi anak didasarkan pada tindakan inderawi anak terhadap lingkungannya, seperti melihat, meraba, membau dan mendengar melalui proses asimilasi dan akomodasi (Bujuri, 2018; Juwantara, 2019). Mengingat pentingnya perkembangan sensori motorik terhadap perkembangan anak selanjutnya, seperti kemampuan kognitifnya, kemampuan sosialnya, dan berkomunikasi dengan orang-orang yang ada disekitarnya, sehingga untuk menstimulasi sensorimotorik pada anak tentunya dibutuhkan media-media yang bisa dimainkan langsung oleh anak, dan melibatkan kemampuan keseimbangan, koordinasi antar anggota tubuh, dan kekuatan tangan, dimana media itu sendiri memberikan tantangan tersendiri bagi anak (Fhatri, 2020; Rosiyanah et al., 2020). Dengan terlibatnya sensorimotorik anak secara langsung, diharapkan dapat memberikan pengalaman tersendiri bagi anak, sehingga anak tidak mengalami kesulitan lagi dalam menyelesaikan tugas-tugas yang berikan guru (Meilanie, 2020). Selain itu kurang tersedianya media pembelajaran dan kurang variatifnya media yang digunakan untuk menstimulasi keterampilan sensori motorik anak, baik di rumah maupun di sekolah dapat menyebabkan keterampilan sensori motorik anak tidak dapat berkembang dengan optimal.

Ketika sistem sensori motorik anak belum berkembang, tubuh akan menjadi tidak nyaman, sehingga menjadi sulit fokus dalam melakukan aktivitas dan berdampak pada proses belajar, mengalami keterlambatan dalam berbicara, dan mengalami kesulitan dalam proses membaca dan menulis (KhoiruzzadiM et al., 2020; Mulyani, 2019). Selain itu keterlambatan perkembangan sensorimotorik juga menyebabkan respon anak menjadi lambat, menjadi sering menangis, tidak bisa duduk diam, senang mengganggu temannya, memiliki emosi yang kurang stabil, sehingga hambatan ini nantinya akan berpengaruh terhadap perkembangan kognitif dan perilaku anak (Bujuri, 2018; Wisnu Budi Wijaya, 2019). Hubungan pengetahuan ibu dengan perkembangan motorik kasar pada anak usia 3-4 tahun, diperoleh hasil bahwa terdapat hubungan yang signifikan antara pengetahuan ibu dengan perkembangan motorik kasar anak usia 3-4 tahun (Muchid et al., 2012). Secara garis besar pengetahuan yang dimiliki ibu sangat mempengaruhi perkembangan motorik kasar anak, dimana ibu yang memiliki pengetahuan terkait pekembangan motorik kasar anaknya, tentu dapat memberikan stimulasi dengan baik. Sebaliknya jika pengetahuan ibu terkait perkembangan motorik anak masih minim, maka anak tidak bisa berkembang secara optimal, dikarenakan para ibu tidak tahu bagaimana caranya memberikan stimulasi yang tepat untuk perkembangan motorik anaknya, misalnya saja para ibu tersebut tidak memberikan kesempatan pada anaknya untuk bermain sensorimotorik seperti tidak boleh bermain pasir, tidak boleh bermain benda-benda cair,tidak boleh bermain ditanah atau rumput-rumputan, dengan alasan takut tangan anaknya menjadi kotor, takut sang anak memasukkan benda tersebut kedalam mulutnya, takut pakaian anaknya menjadi kotor, dan bahkan takut anaknya menjadi luka karena menyentuh benda-benda tertentu. Pengetahuan ibu yang baik akan memberikan hasil yang baik, dimana dengan adanya pengetahuan yang baik terkait dengan pemberian stimulasi motorik anak, maka perkembangan motorik anak akan baik pula (Imelda, 2017; Sukarni et al., 2020). 
Pemberian stimulasi sangat berpengaruh terhadap perkembangan anak, sebab stimulasi merupakan hal yang penting dalam proses tumbuh kembang anak (MAHMUD, 2019; Maulidha \& Larasati, 2017). Anak yang mendapatkan stimulasi yang tepat dan terarah, lebih cepat berkembang daripada anak yang kurang mendapatkan stimulasi. Pemberian stimulasi akan lebih efektif apabila memperhatikan kebutuhan anak dan dilakukan pada masa emas anak, yaitu dua tahun pertama kehidupan anak. Perkembangan motorik yang tidak optimal dapat menyebabkan menurunnya kreatifitas anak dalam beradaptasi, dengan lingkungannya (Ananditha, 2017). Keterlambatan motorik dapat menyebabkan anak merasa ketergantungan, rendah diri, kecemburuan terhadap lingkungannya, penolakan sosial dan memiliki rasa malu terhadap diri sendiri (Maulidha \& Larasati, 2017). Beberapa manfaat yang didapatkan dari adanya pemberian stimulasi terhadap sensorimotorik anak dan perkembangan motorik yang baik, yaitu 1) Dengan melalukan banyak latihan yang penting untuk perkembangan dan kebahagiaan anak, membuat tubuh menjadi lebih ringan, dan terlatih, sehingga memberikan dampak positif bagi kesehatan anak, kesehatan yang baik membuat anak lebih kuat dan aktif untuk beraktivitas. 2) Melalui latihan dan stimulasi yang cukup, anak dapat melepaskan dan menggunakan tenaga yang ada didalam tubuh, sehingga membebaskan tubuh dari kegelisahaan, ketegangan, dan keputusasaan. 3) Anak yang perkembangan motoriknya baik dapat melakukan aktivitas sehari-hari secara mandiri, hal tersebut membuat anak merasa lebih bahagia dan percaya diri. Dengan demikian dapat dikatakan bahwa pemberian stimulasi terhadap sensori motorik dan perkembangan motorik dapat memberikan dampak yang positif terhadap anak (Fitriani, 2018; Octaviani, 2020).

Bermain merupakan kegiatan yang sangat disukai anak-anak, sebab melalui bermain anak dapat bereksperimen dengan sesuatu yang baru, selain itu bermain juga sangat membantu dalam proses perkembangan anak, sehingga dapat dikatakan bahwa bermain tidak dapat dipisahkan dari anak-anak, selain bereksperimen anak juga dapat belajar melalui bermain (Masyhudi et al., 2020; Witasari \& Wiyani, 2020). Banyak manfaat yang didapatkan anak melalui bermain seperti melatih panca indera, melatih gerakan koordinasi anggota tubuh, menjalin interaksi sosial dengan anak lain, dan melatih kemandirian anak. Didalam aktivitas bermain tentunya dibutuhkan media yang menarik, yang dapat menunjang dan menstimulasi perkembangan anak. Alat permainan edukatif merupakan segala bentuk sarana permainan yang sengaja dirancang khusus untuk kepentingan pendidikan, yang dapat mengoptimalkan seluruh aspek perkembangan anak (Ariyanti \& Muslimin, 2015; Lisa et al., 2020). Salah satu alat permainan edukatif yang dapat membuat kegiatan pembelajaran menjadi lebih menyenangkan yaitu Maze. Menurut Asolihin (dalam Muslihin, 2018) menyatakan maze adalah alat permainan yang tebuat dari kayu, yang terdiri dari beberapa jalur yang mana setiap jalurnya diberi warna yang berbeda, sehingga menarik bagi anak. Dengan demikian dapat disimpulkan bahwa alat permainan edukatif Maze adalah alat permainan yang terbuat dari papan dan kayu, yang dibentuk jalur-jalur yang rumit dan berliku, dan anak atau orang yang memainkan bertugas untuk menentukan jalur yang tepat, sesuai dengan tujuan yang sudah ditentukan.

Temuan penelitian sebelumnya menyatakan bahwa penggunaan alat permainan edukatif Maze dapat meningkatkan kemampuan motorik halus anak, selain itu pembelajaran dengan menggunakan alat permainan edukatif Maze juga dapat membantu meningkatkan kemampuan guru dalam proses belajar dan mengajar untuk meningkatkan kemampuan motorik halus anak usia 4-5 tahun (Ariyanti \& Muslimin, 2015; Muslihin, 2018). alat permainan edukatif anak usia dini dirancang untuk mengembangkan aspek perkembangananak salah satunya pengembangan literasi sains (Nityanasari, 2020; Widayati et al., 2021). Alat permainan Maze Dua Sisi (Madasi) ini akan memuat aktivitas yang berkaitan dengan sensori motorik anak seperti keseimbangan, koordinasi antar anggota tubuh,serta kekuatan tangan dan jari, mengenal bentuk dan tekstur benda. Alat permainan edukatif Maze Dua Sisi (Madasi) ini diharapkan mampu membantu menstimulasi keterampilan sensorimotorik anak, seperti melatih keseimbangan, koordinasi dan kekuatan tangan, mengenalkan tekstur dan betuk benda, sehingga anak yang belum mampu melakukan kegiatan tersebut diusianya, mendapatkan kesempatan untuk mengembangkan keterampilan sensori motoriknya. Sebab anak yang tidak biasa dilatihkan atau dibatasi aktivitas sensori motoriknya akan membuat anak menjadi kurang aktif, tidak mau bergerak, membuat beberapa organ tubuhnya menjadi kaku, dan mengalami kesulitan perkembangan diusia tertentu. Tujuan penelitian ini untuk mengembangkan alat permainan edukatif maze dua sisi (MADASI) untuk menstimulasi keterampilan sensori motorik anak. Ada alat permainan edukatif ini diharapkan dapat meningkatkan keterampilan sensori motorik anak.

\section{Metode}

Penelitian ini dilakukan dengan menggunakan pendekatan penelitian pengembangan (Research and Development). Menurut Borg dan Gall (dalam Sugiyono, 2009), penelitian pengembangan adalah suatu proses yang dipakai untuk mengembangkan dan memvalidasi produk pendidikan. Menurut Sugiyono 
(2015) penelitian dan pengembangan merupakan metode penelitian dengan tujuan untuk menghasilkan produk tertentu, serta menguji keefektivan produk tersebut. Desain dalam penelitian ini menggunakan desain ADDIE, yang merupakan singkatan dari Analysis, Design, Delevopment, Implementation, dan Evaluate. Model ini dapat digunakan untuk berbagai macam bentuk pengembangan produk seperti model, metode pembelajaran, media dan bahan ajar. Instrumen merupakan sebuah alat yang digunakan untuk mengumpulkan dan memperoleh data, dalam melakukan sebuah penelitian. Menurut Sugiyono (2009), instrumen penelitian adalah suatu alat yang digunakan untuk mengukur fenomena alam maupun sosial yang diamati, secara spesifik fenomena ini disebut variabel penelitian. Pada penelitian ini instrumen penelitian yang digunakan adalah angket, pemberian skor untuk disetiap butirnya menggunakan skala likert. Adapun kisi-kisi instrumen ahli materi dan ahli media dijabarkan pada Tabel 1 dan 2 .

Tabel 1. Kisi-Kisi Instrumen Ahli Materi

\begin{tabular}{|c|c|c|c|}
\hline No. & Aspek & Indikator & Jumlah Butir \\
\hline 1. & Pembelajaran & $\begin{array}{l}\text { Materi yang disajikan sesuai dengan kebenaran keilmuan } \\
\text { Pengemasan materi sesuai dengan pendekatan keilmuan } \\
\text { Materi relevan dengan aspek yang harus dikuasai oleh } \\
\text { anak }\end{array}$ & 3 \\
\hline 2. & Tujuan & 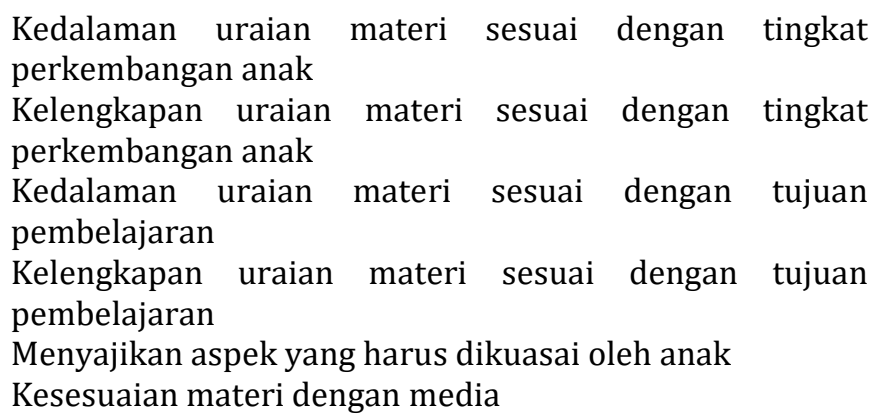 & 7 \\
\hline 3. & Motivasi & $\begin{array}{l}\text { Membangun pengetahuan anak } \\
\text { Mendorong motivasi anak untuk belajar } \\
\text { Mendorong terjadinya interaksi antara anak dengan } \\
\text { sumber belajar } \\
\text { Mendorong anak untuk mengamalkan isi materi. }\end{array}$ & 4 \\
\hline
\end{tabular}

Tabel 2. Kisi-Kisi Instrumen Ahli Media

\begin{tabular}{|c|c|c|c|}
\hline No. & Aspek & Indikator & Jumlah Butir \\
\hline \multirow{10}{*}{1.} & \multirow{9}{*}{ Kualitas } & Ketepatan ukuran Maze Dua Sisi (Madasi) & \multirow[t]{9}{*}{ ( } \\
\hline & & $\begin{array}{l}\text { Ketepatan pemilihan bahan yang digunakan dalam } \\
\text { membuat alat permaian edukatif Maze Dua Sisi (Madasi). } \\
\text { (tripleks dan balok kayu) }\end{array}$ & \\
\hline & & Kekuatan bahan yang digunakan dalam membuat Maze & \\
\hline & & Dua Sisi (Madasi & \\
\hline & & Keawetan bahan yang digunakan dalam membuat Maze & \\
\hline & & Dua Sisi (Madasi) & \\
\hline & & Keamanan bahan yang digunakan dalam membuat Maze & \\
\hline & & Dua Sisi (Madasi) & \\
\hline & & Ketepatan ukuran anakan MazeDuaSisi (Madasi) & \\
\hline & \multirow{4}{*}{ Tampilan } & $\begin{array}{l}\text { Ketepatan pemilihan warna pada anakan Maze Dua Sisi } \\
\text { (Madasi) }\end{array}$ & \multirow{4}{*}{4} \\
\hline \multirow{3}{*}{2.} & & $\begin{array}{l}\text { Kemenarikan alat permainan edukatif MazeDuaSisi } \\
\text { (Madasi) }\end{array}$ & \\
\hline & & $\begin{array}{l}\text { Media didesain dengan sangat menarik, inovatif dan } \\
\text { kreatif }\end{array}$ & \\
\hline & & $\begin{array}{l}\text { Kesesuaian ukuran alat permaianan edukatif Maze Dua } \\
\text { Sisi (Madasi)dengan karakteristik anak }\end{array}$ & \\
\hline 3. & Efektivitas & $\begin{array}{l}\text { Keefektivan alat permainan edukatif Maze Dua Sisi } \\
\text { (Madasi) dalam menstimulasi keterampilan sensori }\end{array}$ & 4 \\
\hline
\end{tabular}




\begin{tabular}{|c|c|c|c|}
\hline No. & Aspek & Indikator & Jumlah Butir \\
\hline 4. & Tambahan & $\begin{array}{l}\text { motorik anak } \\
\text { Alat permainan edukatif Maze Dua Sisi (Madasi) dapat } \\
\text { menciptakan suasana belajar yang menyenangkan } \\
\text { Alat permainan eduatifMaze DuaSisi (Madasi)dapat } \\
\text { menstimulasi keterampilan sensori motorikanak } \\
\text { Kepraktisan alat permainan edukatif Maze Dua Sisi } \\
\text { (Madasi) dalam menstimulasi keterampilan sensori } \\
\text { motorikanak } \\
\text { Kesesuaian alat permainan edukatif Maze Dua Sisi } \\
\text { (Madasi) dengan usia anak } \\
\text { Alat permaian edukatif Maze Dua Sisi (Madasi) sesuai } \\
\text { dengan materi pembelajaran } \\
\text { Kesesuaian alat permainan edukatif Maze Dua Sisi } \\
\text { (Madasi) dengan kemampuan anak } \\
\text { Kemampuan alat permaianan edukatif Maze Dua Sisi } \\
\text { (Madasi) dalam menumbuhkan minat belajaranak } \\
\text { Kesesuaian alat permainan edukatif Madasi (Maze } \\
\text { DuaSisi) dengan tujuan pembelajaran } \\
\text { Kemampuan alat permainan edukatif Maze Dua Sisi } \\
\text { (Madasi)dalam menstimulasi aspek lainnya seperti } \\
\text { melatih konsentrasi anak, kognitif dan kemampuan kerja } \\
\text { sama anak }\end{array}$ & 6 \\
\hline & & Jumlah & 20 \\
\hline
\end{tabular}

Teknik analisis data yang digunakan dalam penelitian ini adalah analisis deskriptif kuantitatif. Teknik analisis deskriptif dilakukan dengan menggunakan statistik deskriptif. Data tersebut diperoleh dari ahli materi dan ahli media berupa koreksi dan masukan. Koreksi dan masukan tersebut digunakan sebagai acuan untuk revisi produk. Sedangkan untuk menganalisis data tentang validitas dari media yang dikembangkan, menggunakan teknik analisis kuantitatif. Teknik analisis kuantitatif dilakukan untuk mendeskripsikan rata-rata skor dari instrumen kelayakan yang diisi oleh ahli terkait dengan media yang dikembangkan. Teknik analisis kuantitaif dipilih untuk menganalisis skor yang diperoleh dari lembar penilaian alat permainan edukatif Maze Dua Sisi (Madasi). Skor yang didapatkan kemudian dirata-ratakan untuk mengetahui validitas media Madasi dengan menggunakan rumus Content Validity Ratio (CVR).

\section{Hasil dan Pembahasan}

Hasil pengembangan produk pada penelitian ini adalah alat permainan edukatif maze dua sisi (madasi) untuk menstimulasi keterampilan sensori motorik anak. Pengembangan alat permainan edukatif maze dua sisi (madasi) dilakukan dengan menggunakan model ADDIE, dengan beberapa tahap yaitu : analisis, perencanaan, pengembangan, implementasi dan evaluasi. Namun pada penelitian ini terdapat tahapan yang tidak dilakukan, yaitu implementasi dan evaluasi. Hal ini dikarenakan keterbatasan waktu, tenaga dan situasi yang tidak mendukung untuk dilakukannya kedua tahapan tersebut. Tahap analisis yang dilakukan pada penelitian ini yaitu menganalisis ketersediaan media pembelajaran yang ada disekolah, khususnya terkait dengan stimulasi keterampilan sensori motorik anak dan bagaimana cara guru membantu menstimulasi keterampilan sensori motorik anak. Hasil analisis yang diperoleh yaitu ketersediaan media pembelajaran untuk membantu menstimulasi keterampilan sensori motorik masih terbatas dan cenderung bersifat monoton. Media yang tersedia hanya puzzle, manik-manik ronce, lego, plastisin dan balok, selebihnya guru lebih banyak menggunakan lembar kerja untuk menstimulasikan keterampilan sensori motorik anak, seperti mewarnai, menempel, menggunting dan menulis. Sehingga kegiatan untuk menstimulasi sensori motorik menjadi kurang menarik bagi anak, dan membuat perhatian anak menjadi mudah teralihkan. Adapun kegiatan bermain maze yang diterapkan untuk menstimulasi sensori motorik anak disekolah tersebut hanya menggunakan kertas dan pensil saja. Hasil analisis tersebut digunakan untuk merancang sebuah media pembelajaran yang sesuai dengan kebutuhan dan permasalahan yang ada.

Tahap desain atau perencanaan pada penelitian ini dilakukan dengan beberapa tahapan yaitu; 1) Menyusun instrumen validasi ahli materi dan ahli media, yang dibuat dalam bentuk angket yang menggunakan tipe jawaban berupa checklist $(\sqrt{ })$. Penggunaan checklist ini digunakan karena peneliti menilai lebih tepat digunakan dalam memberikan penilaian. 2) Mengumpulkan bahan dan perangkaian 
alat permainan. Bahan yang digunakan yaitu teripleks, balok kayu, lem kayu, cat kayu. Balok kayu dan teripleks yang digunakan berukuran 30x30 cm. Untuk permainan jalur berisi mainan kecil berbentuk geometri berukuran $3 \mathrm{~cm}$, sedangkan lebar jalurnya berukuran $1 \mathrm{~cm}$. Ukuran balok pada sisi pemainan labirin yaitu $30 \mathrm{~cm}, 8 \mathrm{~cm}, 21 \mathrm{~cm}$, dan $15 \mathrm{~cm}$. Setelah semua bahan yang dibutuhkan sudah terkumpul, selanjutnya merangkai bahan tersebut menjadi satu. Tahap pengembangan yang dilakukan yaitu dengan menyatukan dua jenis permainan maze, diantaranya maze jalur dan maze labirin menjadi satu alat permainan yang lebih praktis untuk dibawa kemana saja, serta dapat membantu menstimulasi keterampilan sensori motorik anak. Kemudian melakukan validasi ahli dengan dosen ahli materi dan ahli media. Validasi yang dilakukan yaitu dengan memberikan penilaian terhadap materi dan media, serta memberikan masukan yang dapat dijadikan acuan untuk mengembangkan media. Data validitas alat permainan edukatif maze dua sisi (madasi) yang diperoleh dari penilaian dua orang ahli mendapatkan nilai CVR adalah 1,00 dan nilai CVI 1,00 dengan 14 pernyataan pada instrumen materi dan 20 pernyataan pada instrumen media.

Pengembangan alat permainan edukatif maze dua sisi pada penelitian ini terdiri dari (1) uji validitas materi yang terdiri dari 14 butir,(2) uji validitas media yang terdiri dari 20 butir. Hasil validitas kemudian dianalisis dengan menggunakan Content Validity Ratio (CVR) menurut Lawshe,1975 (dalam Sukardi, 2003). Kemudian dilanjutkan dengan menggunakan Content Validity Index (CVI) untuk menghitung rata-rata $C V R$. Berdasarkan perhitungan uji validitas alat permainan edukatif maze dua sisi ditemukan nilai masing-masing CVR 1 dan CVI 1. Hasil penilaian tersebut disajikan pada Tabel 3 dan 4.

Tabel 3. Hasil Uji Validitas Materi

\begin{tabular}{|c|c|c|c|c|c|}
\hline \multirow{2}{*}{ No } & \multirow{2}{*}{ Indikator } & \multicolumn{2}{|c|}{ Ahli } & \multirow{2}{*}{ CVR } & \multirow{2}{*}{ Ket } \\
\hline & & 1 & 2 & & \\
\hline 1. & $\begin{array}{l}\text { Materi yang disajikan sesuai dengan kebenaran } \\
\text { keilmuan }\end{array}$ & 4 & 5 & 1,00 & Valid \\
\hline 2. & $\begin{array}{l}\text { Pengemasan materi sesuai dengan pendekatan } \\
\text { keilmuan }\end{array}$ & 4 & 4 & 1,00 & Valid \\
\hline 3. & Materi relevan dengan aspek yang harus dikuasi anak & 4 & 5 & 1,00 & Valid \\
\hline 4. & $\begin{array}{l}\text { Kedalaman uraian materi sesuai dengan tingkat } \\
\text { perkembangan anak }\end{array}$ & 4 & 4 & 1,00 & Valid \\
\hline 5. & $\begin{array}{l}\text { Kelengkapan uraian materi sesuai dengan tingkat } \\
\text { perkembangan anak }\end{array}$ & 5 & 4 & 1,00 & Valid \\
\hline 6. & $\begin{array}{l}\text { Kedalaman uraian materi sesuai dengan tujuan } \\
\text { pembelajaran }\end{array}$ & 5 & 5 & 1,00 & Valid \\
\hline 7. & $\begin{array}{l}\text { Kelengkapan uraian materi sesuai dengan tujuan } \\
\text { pembelajaran }\end{array}$ & 4 & 4 & 1,00 & Valid \\
\hline 8. & Kesesuaian materi dengan tujuan pembelajaran & 5 & 4 & 1,00 & Valid \\
\hline 9. & Menyajikan aspek yang harus dikuasai anak & 5 & 4 & 1,00 & Valid \\
\hline 10. & Kesesuaian materi dengan media & 4 & 5 & 1,00 & Valid \\
\hline 11. & Membangun pengetahuan anak & 4 & 5 & 1,00 & Valid \\
\hline 12. & Mendorong motivasi anak untuk belajar & 5 & 5 & 1,00 & Valid \\
\hline 13. & $\begin{array}{l}\text { Mendorong terjadinya interaksi antara anak dengan } \\
\text { sumber belajar }\end{array}$ & 4 & 4 & 1,00 & Valid \\
\hline 14. & Mendorong anak untuk mengamalkan isi materi. & 4 & 4 & 1,00 & Valid \\
\hline \multicolumn{4}{|c|}{ CVI } & 1,00 & Valid \\
\hline
\end{tabular}

Tabel 4. Hasil Uji Validitas Media

\begin{tabular}{|c|c|c|c|c|c|}
\hline \multirow{2}{*}{ No } & \multirow{2}{*}{ Indikator } & \multicolumn{2}{|c|}{ Ahli } & \multirow{2}{*}{ CVR } & \multirow{2}{*}{ Ket } \\
\hline & & 1 & 2 & & \\
\hline 1 & Ketepatan ukuran Maze Dua Sisi (Madasi) & 4 & 5 & 1,00 & Valid \\
\hline 2 & $\begin{array}{l}\text { Ketepatan pemilihan bahan yang digunakan dalam } \\
\text { membuat alat permaian edukatif Maze Dua Sisi } \\
\text { (Madasi). (tripleks dan balok kayu) }\end{array}$ & 5 & 5 & 1,00 & Valid \\
\hline 3 & $\begin{array}{l}\text { Kekuatan bahan yang digunakan dalam membuat } \\
\text { Maze Dua Sisi (Madasi) }\end{array}$ & 5 & 5 & 1,00 & Valid \\
\hline 4 & $\begin{array}{l}\text { Keawetan bahan yang digunakan dalam membuat } \\
\text { Maze Dua Sisi (Madasi) }\end{array}$ & 4 & 5 & 1,00 & Valid \\
\hline
\end{tabular}




\begin{tabular}{|c|c|c|c|c|c|}
\hline \multirow{2}{*}{ No } & \multirow{2}{*}{ Indikator } & \multicolumn{2}{|c|}{ Ahli } & \multirow{2}{*}{ CVR } & \multirow{2}{*}{ Ket } \\
\hline & & 1 & 2 & & \\
\hline 5 & $\begin{array}{l}\text { Keamanan bahan yang digunakan dalam membuat } \\
\text { Maze Dua Sisi (Madasi) }\end{array}$ & 5 & 5 & 1,00 & Valid \\
\hline 6 & Ketepatan ukuran anakan Maze DuaSisi (Madasi) & 4 & 4 & 1,00 & Valid \\
\hline 7 & $\begin{array}{l}\text { Ketepatan pemilihan warna pada anakan Maze Dua } \\
\text { Sisi (Madasi) }\end{array}$ & 5 & 5 & 1,00 & Valid \\
\hline 8 & $\begin{array}{l}\text { Kemenarikan alat permainan edukatif Maze Dua Sisi } \\
\text { (Madasi) }\end{array}$ & 4 & 4 & 1,00 & Valid \\
\hline 9 & $\begin{array}{l}\text { Media didesain dengan sangat menarik, inovatif dan } \\
\text { kreatif }\end{array}$ & 5 & 5 & 1,00 & Valid \\
\hline 10 & $\begin{array}{l}\text { Kesesuaian ukuran alat permaianan edukatif Maze } \\
\text { Dua Sisi (Madasi) dengan karakteristik anak }\end{array}$ & 4 & 5 & 1,00 & Valid \\
\hline 11 & $\begin{array}{l}\text { Keefektivan alat permainan edukatif Maze Dua Sisi } \\
\text { (Madasi)dalam menstimulasi keterampilan sensori } \\
\text { motorik anak }\end{array}$ & 5 & 5 & 1,00 & Valid \\
\hline 12 & $\begin{array}{l}\text { Kemampuan alat permainan edukatif Maze Dua Sisi } \\
\text { (Madasi)dalam menciptakan suasana belajar yang } \\
\text { menyenangkan }\end{array}$ & 4 & 5 & 1,00 & Valid \\
\hline 13 & $\begin{array}{l}\text { Alat permainan eduatifMaze Dua Sisi (Madasi) dapat } \\
\text { menstimulasi keterampilan sensori motorik anak }\end{array}$ & 5 & 4 & 1,00 & Valid \\
\hline 14 & $\begin{array}{l}\text { Kepraktisan alat permainan edukatif Maze Dua Sisi } \\
\text { (Madasi) dalam menstimulasi keterampilan sensori } \\
\text { motorik anak anak }\end{array}$ & 5 & 5 & 1,00 & Valid \\
\hline 15 & $\begin{array}{l}\text { Kesesuaian alat permainan edukatif Maze Dua Sisi } \\
\text { (Madasi) dengan usia anak }\end{array}$ & 4 & 5 & 1,00 & Valid \\
\hline 16 & $\begin{array}{l}\text { Alat permaian edukatif MazeDua Sisi (Madasi) sesuai } \\
\text { dengan materi pembelajaran }\end{array}$ & 5 & 5 & 1,00 & Valid \\
\hline 17 & $\begin{array}{l}\text { Kesesuaian alat permainan edukatif Maze Dua Sisi } \\
\text { (Madasi)dengan kemampuan anak }\end{array}$ & 4 & 5 & 1,00 & Valid \\
\hline 18 & $\begin{array}{l}\text { Kemampuan alat permaianan edukatif Maze Dua Sisi } \\
\text { (Madasi) dalam menumbuhkan minat belajar anak }\end{array}$ & 5 & 5 & 1,00 & Valid \\
\hline 19 & $\begin{array}{l}\text { Kesesuaian alat permainan edukatif Madasi (Maze } \\
\text { DuaSisi) dengan tujuan pembelajaran }\end{array}$ & 4 & 4 & 1,00 & Valid \\
\hline 20 & $\begin{array}{l}\text { Kemampuan alat permainan edukatif Maze Dua Sisi } \\
\text { (Madasi)dalam menstimulasi aspek lainnya seperti } \\
\text { melatih konsentrasi anak, kognitif dan kemampuan } \\
\text { kerja sama anak }\end{array}$ & 4 & 4 & 1,00 & Valid \\
\hline \multicolumn{4}{|c|}{ CVI } & 1,00 & Valid \\
\hline
\end{tabular}

Berdasarkan hasil analisis data yang telah dilakukan, dapat disimpulkan bahwa alat permainan yang dikembangkan yaitu berupa alat permainan edukatif maze dua sisi layak diterapkan dalam proses pembelajaran anak usia dini. Alat permainan edukatif maze dua sisi digunakan dalam proses menstimulus keterampilan sensori motori anak disebabkan oleh beberapa faktor yaitu sebagai berikut. Pertama, alat permainan edukatif maze dua sisi layak diterapkan dalam proses pembelajaran dapat membuat siswa tertarik dan termotivasi dalam belajar. Alat permainan edukatif maze dua sisi yang dikembangkan menarik perhatian siswa sehingga membuat siswa termotivasi dalam belajar. Selain itu, media ini sangat dibutuhkan oleh anak. Berdasarkan tahap analisis ketersediaan media pembelajaran untuk membantu menstimulasi keterampilan sensori motorik masih terbatas dan cenderung bersifat monoton. Media yang tersedia hanya puzzle, manik-manik ronce, lego, plastisin dan balok, selebihnya guru lebih banyak menggunakan lembar kerja untuk menstimulasikan keterampilan sensori motorik anak, seperti mewarnai, menempel, menggunting dan menulis. Sehingga kegiatan untuk menstimulasi sensori motorik menjadi kurang menarik bagi anak, dan membuat perhatian anak menjadi mudah teralihkan. Adanya media ini sangat membantu guru dalam melatih sensori motorik anak. Peningkatan keterampilan sensori motorik anak sanggat berdampak positif pada aspek perkembangan yang lain (Fhatri, 2020; Rosiyanah et al., 2020).

Dilihat dari aspek desain, pengembangan yang dilakukan pada produk ini adalah pertama menggabungkan atau permainan gabungan antara dua jenis permainan kedalam satu papan permainan, agar lebih mudah untuk dimainkan oleh anak diwaktu yang bersamaan. kedua adalah ukuran media ini 
dibuat lebih besar, agar dapat dimainkan lebih dari satu anak, sehingga terdapat interaksi antara anak dengan teman bermainnya. yang ketiga media ini lebih banyak memiliki variasi warna, keempat yaitu media ini menjadi lebih praktis untuk dimainkan dalam waktu yang bersamaan, karena dapat dimainkan secara bolak-balik, sehingga pada saat anak merasa sudah selesai memainkan salah satu permainan, anak dapat memainkan permainan yang lain tanpa harus mengambil permainan yang baru dan yang serupa. Memberikan variasi warna dalam kegiatan pembelajaran seperti menyesuaikan bentuk dan warna, kombinasi warna, mengembangkan kreativitas, mengembangkan sensori, melatih koordinasi mata dan tangan, serta menumbuhkan minat anak (Rosiyanah et al., 2020; Yusnia, 2019) .

Selain itu aspek perkembangan yang bisa dikembangkan juga bertambah yaitu melatih kekuatan tangan dan keseimbangan tangan. Sehingga dapat dikatakan bahwa perbedaan antara maze dua sisi (madasi) dengan maze pada umumnya terletak pada desainnya yaitu penggabungan permainan, ukuran media, cara memainkan, kepraktisan dan efisiensi waktu, dan jumlah anak dalam memainkan media tersebut. Terdapat salah satu permainan yang dimainkan dengan menggunakan kardus dan pipet, namun pada Maze Dua Sisi ini menggunakan multipleks dan balok. Berdasarkan hasil pembahasan alat permainan edukasi dapat meningkatkan berbagai keterampilan anak. Pembelajaran dengan menggunakan alat permainan edukatif dapat meningkatkan perkembangan motorik halus anak, bahkan lebih baik dibandingkan dengan tanpa menggunakan alat permainan edukatif pada saat proses pembelajaran (Sihombing, 2015). Temuan ini diperkuat dengan temuan penelitian sebelumnya yang menyatakan menggunakan alat permainan edukatif berpengaruh secara signifikan terhadap perkembangan motorik halus anak (Dea et al., 2021; Khasanah et al., 2011; Lisa et al., 2020; Mubarok, 2021). Maka, dengan penggunaan alat permainan edukatif dalam proses pembelajaran akan membuat pembelajaran menjadi lebih menarik, dan dapat menstimulasikan banyak aspek pekembangan pada anak. Selain itu suasana belajar pun menjadi lebih menyenangkan dan dapat membuat anak menjadi lebih aktif.

\section{Simpulan}

Produk pengembangan yang dihasilkan berupa alat permainan edukatif Maze Dua Sisi (Madasi) ini tidak hanya dapat membantu meningkatkan keterampilan motorik anak saja, melainkan dapat digunakan untuk membantu menstimulasi keterampilan sensori anak seperti mengenal serta merasakan bentuk dan membedakan tekstur. Alat permainan edukatif Maze Dua Sisi (Madasi) disajikan dengan ukuran yang lebih besar dengan warna-warna yang lebih menarik untuk anak. Alat permainan edukatif Maze Dua Sisi (Madasi) dapat dimainkan secara individu maupun berkelompok. Keterbatasan dalam penelitian ini hanya dilaksanakan pada tahap pengembangan, tahap implementasi tidak dapat dilaksanakan karena adanya kebijakan belajar dirumah akibat pandemi covid-19. Direkomendasikan penelitian selanjutnya dapat melanjutkan penelitian ini pada tahap implementasi melalui kegiatan eksperimen, imlikasi penelitian ini diharapkan dapat memberikan dampak pada keterampilan sensori motorik anak menjadi lebih baik.

\section{Daftar Rujukan}

Ananda, R. (2017). Implementasi Nilai-nilai Moral dan Agama pada Anak Usia Dini. Jurnal Obsesi : Jurnal Pendidikan Anak Usia Dini, 1(1), 19. https://doi.org/10.31004/obsesi.v1i1.28.

Ananditha, A. C. (2017). Faktor-Faktor Yang Berhubungan Dengan Perkembangan Motorik Kasar Pada Anak Toddler. Jurnal Keperawatan Muhammadiyah, 2(1). http://repository.umsurabaya.ac.id/id/eprint/2970\%0A.

Ariyanti, A., \& Muslimin, Z. (2015). Efektivitas Alat Permainan Edukatif (APE) Berbasis Media Dalam Meningkatkan Kemampuan Berhitung Pada Anak Kelas 2 Di SDN 2 Wonotirto Bulu Temanggung. $\begin{array}{llll}\text { Jurnal Psikologi } & \text { Tabularasa, } & \text { 58-69). }\end{array}$ https://jurnal.unmer.ac.id/index.php/jpt/article/view/243.

Bujuri, D. A. (2018). Analisis Perkembangan Kognitif Anak Usia Dasar dan Implikasinya dalam Kegiatan Belajar Mengajar. LITERASI (Jurnal Ilmu Pendidikan), 9(1), 37. https://doi.org/10.21927/literasi.2018.

Dea, L. F., Yusuf, M., Anwar, M. S., Choirudin, C., \& Juniati, D. A. (2021). Alat Permainan Edukatif Golf Anak Usia Dini sebagai Program Edupreneur Prodi Pendidikan Islam Anak Usia Dini. Golden Age: Jurnal Ilmiah Tumbuh Kembang Anak Usia Dini, 6(1), 25-36. https://doi.org/10.14421/jga.2021.61-03.

Fhatri, Z. (2020). Intervensi Latihan Sensori Motorik Dalam Pengembangan Kinestetik Anak Autis. Tarbawy: Jurnal Pendidikan Islam, 7(1), 23-36. https://doi.org/10.32923/tarbawy.v7i1.1184.

Fitriani, R. (2018). Perkembangan Fisik Motorik Anak Usia Dini. Jurnal Golden Age, 2(01), 25. https://doi.org/10.29408/goldenage.v2i01.742. 
Imelda. (2017). Pengetahuan Ibu Tentang Pemberian Stimulasi Dan Perkembangan Anak Pra Sekolah (3-5 Tahun) Di Banda Aceh. Idea Nursing Journal, 8(3). https://doi.org/10.52199/inj.v8i3.9487.

Juwantara, R. A. (2019). Analisis Teori Perkembangan Kognitif Piaget pada Tahap Anak Usia Operasional Konkret 7-12 Tahun dalam Pembelajaran Matematika. Al-Adzka: Jurnal Ilmiah Pendidikan Guru Madrasah Ibtidaiyah, 9(1), 27. https://doi.org/10.18592/aladzkapgmi.v9i1.3011.

Khasanah, I., Prasetyo, A., \& Rakhmawati, E. (2011). Permainan Tradisional sebagai Media Stimulasi Aspek Perkembangan Anak Usia Dini. Jurnal Pendidika PAUDIA, 1(1), 59-74. https://doi.org/10.26877/paudia.v1i1.261.

KhoiruzzadiM, BarokahM, \& KamilaA. (2020). Upaya Guru Dalam Memaksimalkan Perkembangan Kognitif, Sosial dan Motorik Anak Usia Dini. JECED: Journal of Early Childhood Education and Development, 2(1), 40-51. https://doi.org/10.15642/jeced.v2i1.561.

Lisa, M., Mustika, A., \& Lathifah, N. S. (2020). Alat Permainan Edukasi (APE) Meningkatkan Perkembangan Motorik Halus pada Anak Usia 4-6 Tahun. Jurnal Kesehatan, 11(1), 125. https://doi.org/10.26630/jk.v11i1.1584.

MAHMUD, B. (2019). Urgensi Stimulasi Kemampuan Motorik Kasar Pada Anak Usia Dini. DIDAKTIKA: Jurnal Kependidikan, 12(1), 76-87. https://doi.org/10.30863/didaktika.v12i1.177.

Masyhudi, A. A., Anna, C., Afifah, N., Teknik, F., Surabaya, U. N., Timur, J., Program, D., Tata, S., Teknik, F., Surabaya, U. N., \& Timur, J. (2020). Media permainan monopoli sebagai media edukasi pangan sumber protein bagi anak. 2(1), 19-34. https://journal.unesa.ac.id/index.php/JOFC.

Maulidha, M., \& Larasati, D. (2017). Faktor-Faktor yang Mempengaruhi Keterlambatan Perkembangan Anak Usia 1-3 Tahun di Desa Cangkringsari Kecamatan Sukodono Kabupeten Sidoarjo. Journal Of Issues In Midwifery, 1(1), 51-70. https://doi.org/10.21776/ub.joim.2017.001.01.6.

Meilanie, R. S. M. (2020). Survei Kemampuan Guru dan Orangtua dalam Stimulasi Dini Sensori pada Anak Usia Dini. Jurnal Obsesi: Jurnal Pendidikan Anak Usia Dini, 5(1), 958-964. https://doi.org/10.31004/obsesi.v5i1.741.

Mubarok, A. A. S. A. Al. (2021). Alat Permainan Edukatif dalam Menanamkan Nilai Agama dan Moral Anak Usia Dini. Jurnal Inovasi Pendidikan Guru Raudhatul Atfha, 9(1). https://doi.org/10.21043/thufula.v9i1.10103.

Muchid, A., Samiasih, A., \& Mariyam. (2012). Hubungan Pengetahuan Ibu Dengan Perkembangan Motorik Kasar Anak Usia 3-4 Tahun Di Posyandu Budi Lestari Desa Tlogorejo Guntur Demak. Hubungan Pengetahuan Ibu Dengan Perkembangan Motorik Kasar Anak Usia 3-4 Tahun Di Posyandu Budi Lestari Desa Tlogorejo Guntur Demak, 6(1), 36-43.

Mulyani, N. (2019). Pengembangan Kreativitas Anak Usia Dini Melalui Bermain Gerak Dan Lagu Di TK Negeri Pembina Kabupaten Purbalingga. As-Sibyan : Jurnal Pendidikan Anak Usia Dini, 4(1), 13-24. https://doi.org/10.32678/as-sibyan.v4i1.1961.

Muslihin, H. Y. (2018). Penggunaan Alat Permainan Edukatif ( Ape ) Maze Untuk Meningkatkan Motorik Halus Anak Usia 4-5 Tahun. Jurnal PAUD Agapedia, 2(2), 175-186. https://doi.org/10.17509/jpa.v2i2.24543.

Nityanasari, D. (2020). Alat Permainan Edukatif Pasak Warna Untuk Meningkatkan Kemampuan Mengenal Warna Pada Anak Usia Dini. Jurnal Pendidikan Anak Usia Din, 4(1), 9-14. https://doi.org/10.24853/yby.4.1.9-14.

Nurdin, N., \& Anhusadar, L. (2020). Efektivitas Pembelajaran Online Pendidik PAUD di Tengah Pandemi Covid 19. Jurnal Obsesi : Jurnal Pendidikan Anak Usia Dini, 5(1), 686. https://doi.org/10.31004/obsesi.v5i1.699.

Nurohmah, A. N., \& Dewi, D. A. (2021). Penanaman Nilai Moral dan Karakter di Era Pandemi melalui Pendidikan dengan Mengimplementasikan Nilai-Nilai Pancasila. Journal of Education, Psychology and Counseling, 3(1), 119-128. https://ummaspul.e-journal.id/Edupsycouns/article/view/1305.

Octaviani, N. R. (2020). Pengaruh Pola Asuh Orang Tua dan Disiplin Belajar Terhadap Hasil Belajar PPKn Siswa Kelas V SDN Dabin I Kecamatan Tegal Selatan Kota Tegal.

Rakhmayanti, E., \& Subagio, M. (2019). Efektivitas Penggunaan Media Monopoli Tematik Terhadap Aktivitas Dan Hasil Belajar Kognitif Siswa Kelas Iv Di Sd Negeri Sumput Sidoarjo. Jurnal Penelitian Pendidikan Guru Sekolah Dasar, 7(3), 2975-2984.

Rosiyanah, R., Yufiarti, Y., \& Meilani, S. M. (2020). Pengembangan Media Stimulasi Sensori Anak Usia 4-6 Tahun Berbasis Aktivitas Bermain Tujuh Indera. Jurnal Obsesi : Jurnal Pendidikan Anak Usia Dini, 5(1), 941-956. https://doi.org/10.31004/obsesi.v5i1.758.

Sasmito, D. R. P., \& Trimulyono, G. (2019). Development of Funginopoly (Fungi Monopoly) Game Media In Fungi Material For 10th Grade Senior High School to Increase Student's Level of Concept Understanding. BioEdu, 8(3), 51-60.

Sihombing, A. S. (2015). Pengaruh Alat Permainan Edukatif Dalam Mengembangkan Motorik Halus Anak 
Usia 5-6 Tahun Di TK Khatolik Assisi Medan T.A. 2012-2013. Bunga Rampai Usia Emas, 1(2), 13-23. http://digilib.unimed.ac.id/id/eprint/7578.

Sugiyono. (n.d.). Metode Penelitian Pendidikan (Pendekatan Kuantitatif, Kualitatif, dan R\&D). Alfabeta.

Sugiyono. (2009). Metode Penelitian Kuantitatif dan Kualitatif dan R\&D. ALFABETA.

Sukardi. (2003). Metodologi Penelitian Pendidikan. Bumi Aksara.

Sukarni, Sudirman, \& Yusuf, H. (2020). Hubungan Konseling Keluarga Berencana dan Pengetahuan Ibu Dengan Pemilihan Metode Kontrasepsi Di Wilayah Kerja Puskesmas Mamboro. Jurnal Kolaboratif Sains, 1(1), 339-348. https://doi.org/10.31934/jom.v1i1.1182.

Widayati, J. R., Safrina, R., \& Supriyati, E. (2021). Analisis Pengembangan Literasi Sains Anak Usia Dini melalui Alat Permainan Edukatif. Jurnal Obsesi : Jurnal Pendidikan Anak Usia Dini, 5(1), $654-664$. https://doi.org/10.31004/obsesi.v5i1.692.

Wisnu Budi Wijaya, I. K. (2019). Menanamkan Konsep Catur Paramita Pada Anak Usia Dini Di Lingkungan Keluarga Dan Sekolah. Pratama Widya: Jurnal Pendidikan Anak Usia Dini, 3(2), 41-46. https://doi.org/10.25078/pw.v3i2.737.

Witasari, O., \& Wiyani, N. A. (2020). Permainan Tradisional untuk Membentuk Karakter Anak Usia Dini. JECED : Journal of Early Childhood Education and Development, 2(1), 52-63. https://doi.org/10.15642/jeced.v2i1.567.

Wulandari, H., \& Purwanta, E. (2021). Pendidikan Anak Usia Dini Pencapaian Perkembangan Anak Usia Dini di TK selama Pembelajaran Daring saat Pandemi Covid-19. Jurnal Obsesi : Jurnal Pendidikan Anak Usia Dini, 5(1), 452-462. https://doi.org/10.31004/obsesi.v5i1.626.

Yusnia, Y. (2019). Penggunaan Media Video Scribe Dalam Pembelajaran Literasi Sains Untuk Mahasiswa PGPAUD. Cakrawala Dini: Jurnal Pendidikan Anak Usia Dini, 10(1), 71-75. https://doi.org/10.17509/cd.v10i1.17436. 